\title{
Sprawozdanie z pobytu w Instytucie Józefa Pilsudskiego w Londynie w 2016 r.
}

W trakcie dwutygodniowego (21 listopada - 2 grudnia 2016 r.) pobytu w Instytucie Józefa Piłsudskiego w Londynie przeglądnięte zostały wszystkie luźne fotografie dotyczące Józefa Piłsudskiego (ok. 1500 obiektów). Będzie to pierwsza kolekcja luźnych fotografii. W ustaleniu z przedstawicielem Instytutu uzgodniono następujące założenia systematyzacji fotografii dotyczących patrona Instytutu: 1. Fotografie indywidualne i portretowe; 2. Fotografie z rodziną i bliskimi osobami; 3. Fotografie z czasów wojennych, uroczystości oficjalnych, państwowych; 4. Fotografie z uroczystości pogrzebowych; 5. Fotografie dokumentujące portrety i rzeźby upamiętniające Marszałka. Wyłączono wszystkie dublety, pozostawiając najstarszy możliwy do identyfikacji oryginał lub najstarszą kopię, za wyjątkiem przypadków, gdy na duplikacie była dedykacja lub autograf. Pozostawiono też kopię z bardziej precyzyjnym opisem na odwrocie. Wyłączone poszczególne duplikaty jednego ujęcia spięto razem. Ze zbioru zdjęć wyłączono również pocztówki i ulotki. Pocztówki, zgodnie z decyzją przedstawiciela Instytutu, będą stanowić oddzielną kolekcję. Odłożono również osobno fotografie w formacie przekraczającym rozmiar największej koszulki poliestrowej (A4), co uniemożliwiało wpięcie jej w segregator na zdjęcia.

W ramach $5 \mathrm{ww}$. grup tematycznych ułożono fotografie chronologicznie (według chronologii ujęć, a nie powstania odbitki). Następnie umieszczono w foliach ochronnych poliestrowych i segregatorach na zdjęcia. Najwięcej zdjęć znalazło się w 4 grupie (Fotografie z uroczystości pogrzebowych), zajęły aż 3 segregatory oraz w grupie 3 (Fotografie z czasów wojennych, uroczystości państwowych, oficjalnych) - zajęły 2 segregatory na fotografie.

Omówiona wcześniej systematyzacja zdjęć przedstawiających Józefa Piłsudskiego, ułatwia dostęp już teraz do poszukiwanego ujęcia z jego życia. Pozostaje jedynie ostatni etap prac porządkowych - wpisanie opisu zdjęcia do bazy danych - w niektórych przypadkach wiązać się to będzie z dokonaniem kwerendy, gdyż nie wszystkie fotografie mają naniesiony opis. W tych wypadkach trzeba będzie porównać fotografie $\mathrm{z}$ istniejącymi albumami w Instytucie lub dostępnymi zdigitalizowanymi i udostępnionymi online odbitkami z innych zasobów, np. Narodowego Archiwum Cyfrowego.

W przyszłości należałoby w podobny sposób posegregować fotografie dotyczące innych tematów, kontynuować systematyzację według poszczególnych grup tematycznych, a następnie uwzględniać opisy zdjęć w bazach danych Instytutu. Kolejność prac porządkowych określiłby Instytut, biorąc pod uwagę priorytety związane z jego działalnością. Wydaje się oczywiste, że powinny to być fotografie z czasów legionowych i Polskiej Organizacji Wojskowej, pierwszych lat niepodległości i wojny polsko-bolszewickiej, co związane jest z nadchodzącą 100. rocznicą odzyskania przez Polskę niepodległości.

Sylwester Rękas

Archiwum Narodowe w Krakowie 